\title{
PALAEOMAGNETISM AND K/AR AGES OF SOME IGNEOUS ROCKS OF THE TRINDADE COMPLEX AND THE VALADO FORMATION, FROM TRINDADE ISLAND, BRAZIL
}

\author{
DANIEL ALBERTO VALENCIO* and JOSÉ ERNESTO MENDIA*
}

\begin{abstract}
Palaeomagnetic and radiometric data of seven igneous units from Trindade Island are given. They support the age of $2.41 \pm 0.05 \mathrm{~m}$.y. for the polarity transition between the Matuyama reversed and the Gauss normal epochs.

On the basis of the mean direction of cleaned remanent magnetization of each igneous unit a virtual geomagnetic pole is computed; the mean of these virtual geomagnetic poles is $86^{\circ} \mathrm{S}, 5^{\circ} \mathrm{E}$, $\alpha_{95}=4$; it would represent the Late Cenozoic palaeomagnetic pole for the Trindade Island.

It is suggested that the normal polarity found in igneous rocks from Argentina would represent a continental evidence for the existence of the short normal polarity event at the beginning of the Matuyama reversed epoch suggested on the basis of seafloor spreading data.
\end{abstract}

RESUMO São apresentados dados radiométricos e paleomagnéticos de sete unidades magmáticas da Ilha de Trindade. Eles apóiam a idade de $2,41 \pm 0,05 \mathrm{~m}$.a. para a transiçåo de polaridade entre as epocas reversa de Matuyama e normal de Gauss.

Com base nas direções médias da direção remanente lavada de cada unidade magmática, foi calculado um pólo geomagnético virtual; a média desses pólos geomagnéticos virtuais é $86^{\circ} \mathrm{S}, 5^{\circ} \mathrm{E}$, $\alpha_{95}=4$; representaria o pólo paleomagnético do Cenozóico Superior para a Ilha de Trindade.

Sugere-se que a polaridade normal encontrada em rochas magmáticas da Argentina representaria uma evidência continental da existéncia do evento curto de polaridade normal no início da época reversa de Matuyama sugerida com base nos dados da expansão do fundo dos oceanos.

INTRODUCTION It has been shown that although the principal features of the geomagnetic-time scale are well defined the finer details are hard to establish. One of the reasons for this is that potassium-argon dating has a limited resolution which explains that the shorter magnetic events within the longer epochs are difficult to define precisely.

In 1970 Valencio et al. have discussed the available palaeomagnetic-radiometric data close to the boundary between the Matuyama reversed and the Gauss normal epochs and showed that the age of this boundary was poorly defined.

Errors involved in the K-Ar ages of some Late Cenozoic igneous rocks from the Brazilian Trindade Island are lesser than 5\%. Particularly, the K-Ar ages of some of these igneous rocks are close to the Gauss-Matuyama polarity transition. Therefore the palaeomagnetic study of the igneous rocks from Trindade Island could be useful to define the Late Cenozoic reversals of the geomagnetic field and particularly those ones which could have occurred close to the Gauss-Matuyama polarity transition. A collection of oriented hand samples of some igneous rocks from Trindade Island was carried out in 1970. The results of the palaeomagnetic study of these rocks, as well as those of a complementary $\mathrm{K}$-Ar dating of them, are given in this paper.

* Laboratorio de Paleomagnetismo, Departamento de Ciencias Geologicas, Facultad de Ciencias Exactas y Naturales, Universidad de Buenos Aires. Ciudad Universitaria, Pabellón 2 Buenos Aires, Argentina 
New palaeómagnetic and radiometric data related to the Gauss-Matuyama polarity transition have been published after 1970. Particularly those coming from igneous rocks of the Norfolk Island provide an excellent statistical estimate of $2.41 \pm 0.05$ m.y. for the age of this boundary (McDougall et al., 1972). It is shown that the palaeomagnetic data and $\mathrm{K}$-Ar ages of some of the igneous rocks from Trindade Island support this estimate.

THE GEOLOGY OF THE TRINDADE ISLAND Trindade Island is situated in the South Atlantic Ocean, about $1,150 \mathrm{~km}$ off the Brazilian coast and $1,800 \mathrm{~km}$ west of the Mid Atlantic Ridge, at longitude $29^{\circ} 20^{\prime}$. West and latitude $20^{\circ} 31^{\prime}$ South. The geology of the island has been described by Almeida, whose nomenclature will be followed here. Fig. I shows a geological sketch map of Trindade Island based on the map made by Almeida (1961). This author suggests that the heterogeneous basal pyroclastic rocks of the island originated in different volcanic episodes and includes them in the Trindade Complex. These pyroclastic rocks are cut by intrusive bodies of phonolitic and ultrabasic character which are also assigned to the Trindade Complex. The largest of these intrusions is the Pico Branco, in the southern part of the island (Fig. 1). After a quiet period during which the rocks of the Trindade Complex were eroded, four successive volcanic cycles occurred. Rocks that originated in these volcanic cycles were included, in chronological order, in the Desejado Sequence, the Morro Vermelho Formation, the Valado Formation and the Vulcão do Paredão Formation. The Desejado Sequence, formed by flows of phonolite, grazinite and nephelinite interbedded with pyroclastic rocks of the same characteristics, overlays the Trindade Complex. The Morro Vermelho Formation, formed by flows of ankaratritic character, is exposed in the eastern part of the island (Fig. 1). The third,volcanic cycle produced pyroclastic deposits and flows of the Ponta do Valado (northern coast, Fig. 1) and the tuffs of the Praia do Principe (southern coast), which are included in the Valado Formation. The exposures of the Vulcão do Paredão Formation in the eastern part of the island were formed in the last volcanic cycle.

On the basis of morphologic evidence, Almeida has suggested a pre-glaciation (Pleistocene-Pliocene) age for the Trindade Complex. The author has also assigned to the Pleistocene the Morro Vermelho Formation and to the Wisconsin (post Pleistocene) the Valado Formation.

Dating of rocks of the Trindade Complex; the Desejado Sequence and the. Morro Vermelho Formation was undertaken by the K-Ar method, mainly on whole rock samples, by Cordani (1968). On the basis of the radiometric data he suggests that most of the intrusive rocks of the Trindade Complex were formed during episodes occurred between about 2.90 and 2.30 m.y.b.p.; and that the Desejado Sequence includes lava flows occurred between 2.30 and 1.50 m.y.b.p. Cordani also suggests that rocks of the Morro Vermelho Formation were formed before than 0.17 m.y.b.p. and that the Valado and the Vulcáo do Paredão Formations are of post-Pleistocene age.

PALAEOMAGNETIC RESULTS There is only one mean of communication between the Trindade Island and the continent: a ship of the Diretoria de Hidrografia e Navegação of Brazil. This ship undertakes periodical visits to the island staying in it by periods of about 24 hours. The samples for the palaeomagnetic study were collected by one of us (J.M.) during one of these visits in 1970. The lack of any transportation in land and the short time available did not allow us to collect all the rock exposures whose $\mathrm{K}$-Ar ages are close to the Gauss-Matuyama polarity transition. Sampling of the igneous rocks of the Trindade Complex was undertaken in seven separate places (Fig. 1 and Table I); in general three or four oriented hand samples were obtained from each rock unit sampled. 


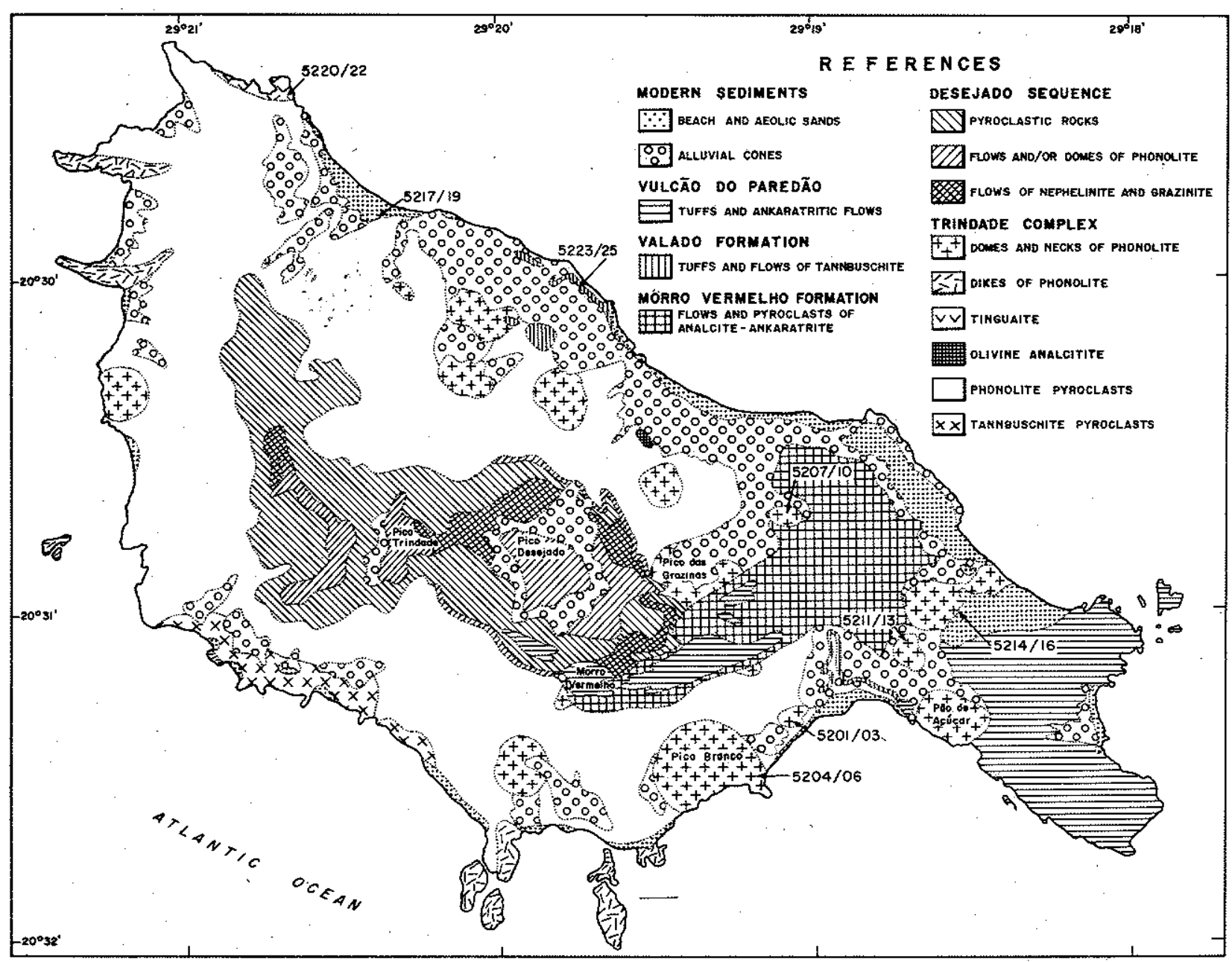

Figure 1 - Schematic geological map of Trindade Island (4) and sampling localities for the palaeomagnetic ștudy 
Table I - Palaeomagnetic data and virtual geomagnetic poles from Trindade Island

\begin{tabular}{|c|c|c|c|c|c|c|c|c|c|c|c|c|c|}
\hline \multirow[b]{2}{*}{$\begin{array}{l}\text { Geologic } \\
\text { Unit }\end{array}$} & \multirow[b]{2}{*}{ Rock Unit } & \multirow[b]{2}{*}{$\begin{array}{l}\text { Sample } \\
\text { Number }\end{array}$} & \multicolumn{5}{|c|}{ Rock unit mean palaeomagnetic data } & \multirow[b]{2}{*}{ K-Ar age (m.y.) } & \multicolumn{4}{|c|}{ Virtual geomagnetic pole } & \multirow[b]{2}{*}{ Symbol } \\
\hline & & & $\begin{array}{l}\text { No. of } \\
\text { Samples }\end{array}$ & $\mathrm{D}\left({ }^{\circ}\right)$ & $I\left({ }^{\circ}\right)$ & $95\left(^{\circ}\right)$ & Polarity & & $\begin{array}{l}\text { Latitude } \\
\text { South }\left(^{\circ}\right)\end{array}$ & $\begin{array}{l}\text { Longitude } \\
\text { East }\left({ }^{\circ}\right)\end{array}$ & $\begin{array}{l}\mathrm{d} \psi \\
\left({ }^{\circ}\right) \alpha_{9}\end{array}$ & $\begin{array}{r}\mathrm{d} \chi \\
{ }_{9}\left({ }^{\circ}\right) \\
0^{2}\end{array}$ & \\
\hline & $\begin{array}{l}\text { Neck of phonolite } \\
\text { Praia Príncipe }\end{array}$ & $5201-5203$ & 3 & 1.0 & -39.2 & 3.5 & $\mathrm{~N}$ & $2.43 \pm 0.11(2)$ & 88.1 & 302.2 & 2.5 & 4.2 & $\odot$ \\
\hline Trindade & $\begin{array}{l}\text { Neck of phonolite } \\
\text { Pico Branco }\end{array}$ & $5204-5206$ & 3 & 356.1 & -44.1 & 8.8 & $\mathbf{N}$ & $2.57 \pm 0.13(2)$ & 83.6 & 3.5 & 6.9 & 11.1 & $\Delta$ \\
\hline \multirow[t]{5}{*}{ Complex } & $\begin{array}{l}\text { Neck of phonolite } \\
\text { Pico Preto }\end{array}$ & $5207-5210$ & 4 & - & - & - & - & $2.77 \pm 0.10(2)$ & - & - & - & - & - \\
\hline & $\begin{array}{l}\text { Neck of phonolite } \\
\text { Pico do Vigia }\end{array}$ & $5211-5213$ & 3 & 7.8 & -42.0 & 14.4 & $\mathbf{N}$ & $2.80 \pm 0.50$ & 81.9 & 269.4 & 10.9 & 17.7 & $\Xi$ \\
\hline & $\begin{array}{l}\text { Neck of phonolite } \\
\text { Pico N. S. de Lourdes }\end{array}$ & $5214-5216$ & 3 & 354.0 & -42.4 & 6.9 & $\mathbf{N}$ & $6.4 \pm 3.5$ & 83.2 & 23.5 & 5.3 & 8.5 & $\odot$ \\
\hline & $\begin{array}{l}\text { Dyke of nephelinite, } \\
\text { Praia dos Cabritos }\end{array}$ & $5217-5219$ & 3 & 352.9 & -41.4 & 5.5 & $\mathrm{~N}$ & $2.55 \pm 0.22(2)$ & 82.7 & 32.7 & 4.1 & 6.7 & $\odot$ \\
\hline & $\begin{array}{l}\text { Tinguaite, Crista do } \\
\text { Galo }\end{array}$ & $5220-5222$ & 3 & 359.9 & -37.7 & 3.3 & $\mathrm{~N}$ & $2.55 \pm 0.08(2)$ & 89.3 & 339.0 & 2.3 & 3.9 & $\nabla$ \\
\hline $\begin{array}{l}\text { Valado } \\
\text { Formation }\end{array}$ & $\begin{array}{l}\text { Flow of Tannsbuchite, } \\
\text { Ponta do Valado }\end{array}$ & $5223-5225$ & 3 & 348.9 & -44.4 & 26.5 & $N$ & $1.2 \pm 1.0$ & 78.4 & 29.7 & 20.9 & 33.3 & $\odot$ \\
\hline - & & & $\begin{array}{l}\text { Mean of } v \\
\text { and Vala }\end{array}$ & $\begin{array}{l}\text { irtual g } \\
\text { do Forn }\end{array}$ & $\begin{array}{l}\text { omagn } \\
\text { nation }\end{array}$ & ic pole & $S$ of the $T x$ & indade Complex & 85.6 & 5.3 & 4 & & $*$ \\
\hline
\end{tabular}


Also three oriented hand samples of a flow of the Valado Formation were collected close to the Ponta do Valado in the northern coast of the island. A total of 25 oriented hand samples were obtained. In Table I is indicated the number assigned to each hand sample of a rock unit; Fig. 1 shows the sites from which oriented samples were collected.

The palaeomagnetic measurements were made in the laboratory of the University of Buenos Aires, Argentina. Three disks $2.5 \mathrm{~cm}$ in diameter and $1 \mathrm{~cm}$ thick were cut of each sample. A total of 25 oriented specimens were obtained. Natural remanent magnetization of these disks was measured using a spinner magnetometer. Fig. 2 shows the directions of natural remanent magnetization of samples from each geological unit; note that the n.r.m. of all the samples is of normal polarity and the scattering between the direction of n.r.m. of different units. To remove unstable components partial a.f. demagnetization experiments were carried out. One disk of each sample was subjected to a.f. demagnetizing fields increasing in steps of 50 oersteds to 300 oersteds. So the best a.f. demagnetizing field isolating the thermic remanence of each sample was determined. The criterion adopted for the choice of the best a.f. demagnetizing field strength was that the direction of the remanence of the pilot specimen exhibited no further change in response to higher demagnetizing field strengths. For most samples the best a.f. demagnetizing field strengths varied from 100 to 200 oersteds. A second and sometimes a third specimen of the same sample was submitted to this a.f. demagnetizing field for the definition of the direction of the thermic remanence of each sample. High a.f. coercivities were found to be associated with stable n.r.m.; this was the case for most of the samples from the rocks of phonolite of Praia Príncipe, Pico Branco, and Pico do Vigia.

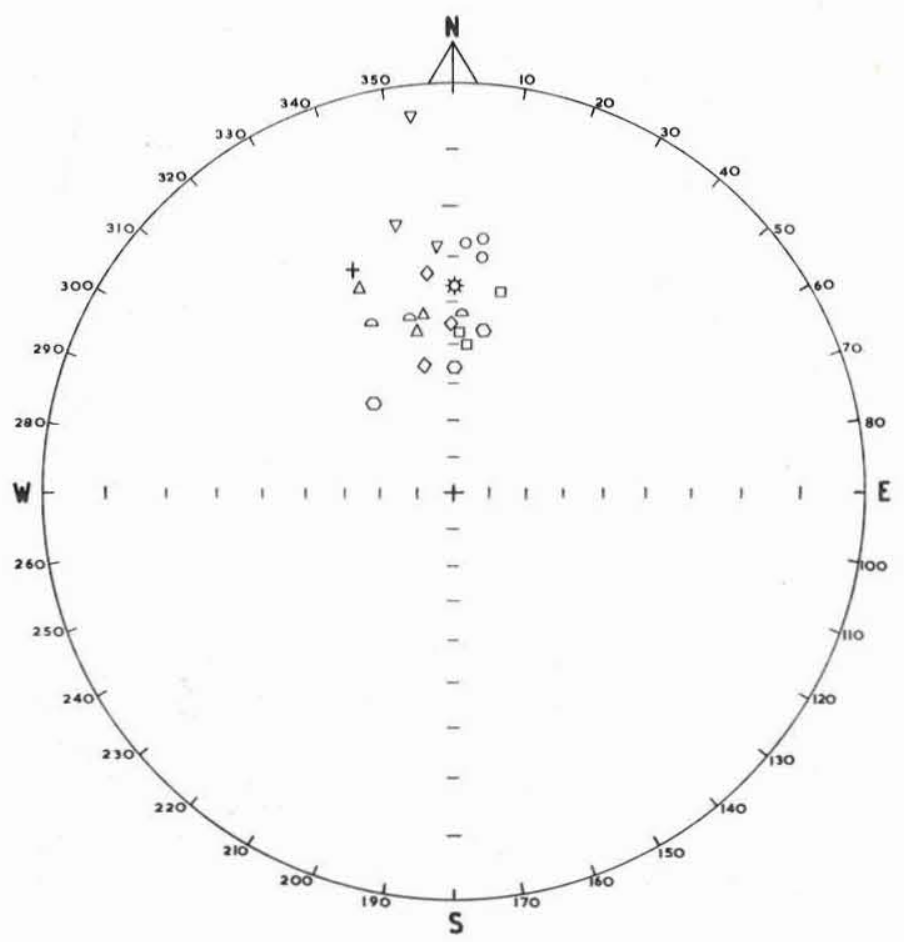

Figure 2 - Trindade Island. Directions of natural remanent magnetization of hand samples before cleaning; the key to the symbols for the different geological units is as given in Table I. The directions of the present geomagnetic field and of the axial dipole field are shown by + and ${ }^{-}$-respectively 


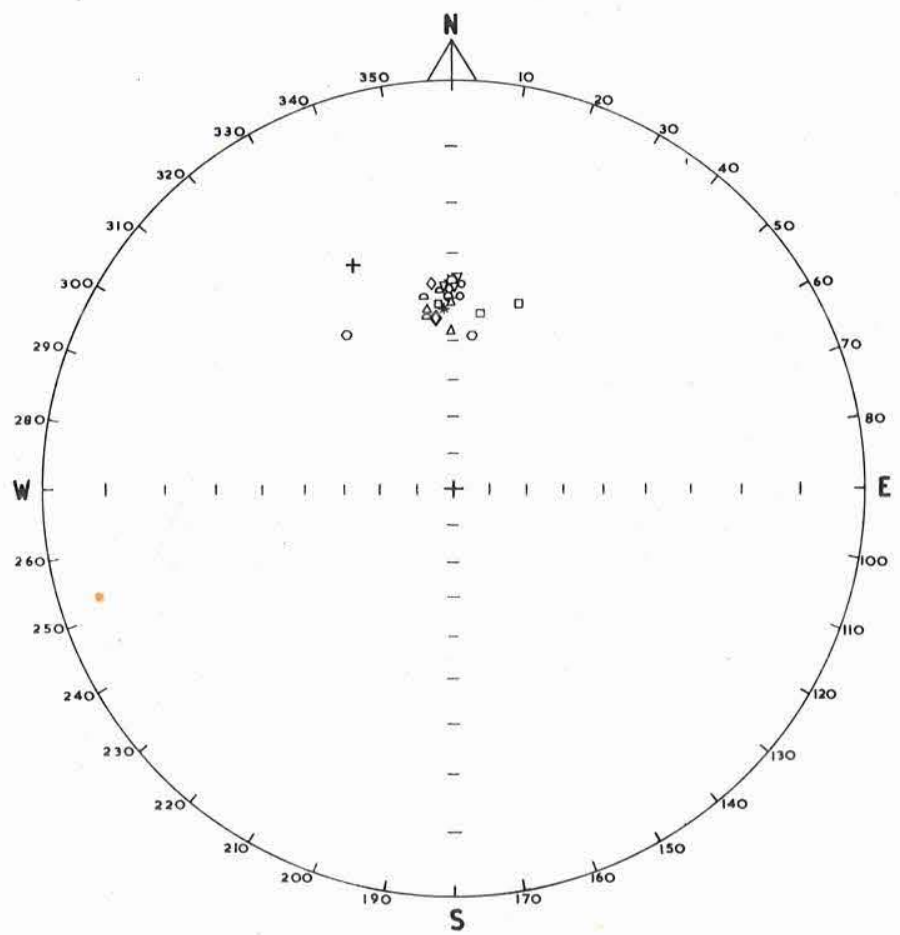

Figure 3 - Trindade Island. Directions of natural remanent magnetization of hand samples after cleaning. The key to the symbols is as given in Table I and Fig. 2

Samples from the neck of phonolite of Pico Preto did not give reliable results; they have shown unstable n.r.m. The other six units of the Trindade Complex and that of the Valado Formation shows stable thermic remanent magnetization. Fig. 3 shows the directions of the cleaned remanent magnetization of samples from the stable units. Note that after a.f. cleaning the remanent magnetization of samples from all the units fell into a compact group. All the samples have normal cleaned remanent magnetization. In Table I the mean directions of the cleaned remanent magnetization of each rock unit are given. Virtual geomagnetic poles for each one of these rock units are also given in this table. Fig. 4 shows these virtual geomagnetic poles.

K-Ar AGE DETERMINATIONS K-Ar age determinations for the necks of phonolite of Praia Príncipe, Pico Branco, and Pico Preto, for the dyke of nephelinite of Praia dos Cabritos and for the Tinguaite of Crista do Galo, of the Trindade Complex (Table I), were undertaken by Cordani in 1968 in the radiometric laboratories of the University of São Paulo, Brazil. Description of the method used may be found in the well detailed Cordani's doctoral thesis.

The K-Ar age determinations (whole rock) for the necks of phonolite of the Pico Nossa Senhora de Lourdes, and Pico do Vigia, both of the Trindade Complex, and for the flow of tannbuschite of Ponta do Valado of the Valado Formation (Table I) were made on the actual samples on which the palaeomagnetic measurements were done. The determinations were carried out by E. Linares in the radiometric laboratories of the Instituto Nacional de Geologia Isotópica mounted in the University of Buenos Aires, Argentina. Techniques of measurements were similar to those described previously. Before dating the samples were carefully examined in thin sections by C. Latorre. 
Figure 4 - Trindade Island. Positions of virtual geomagnetic poles. The key to the symbols is as given in Table I

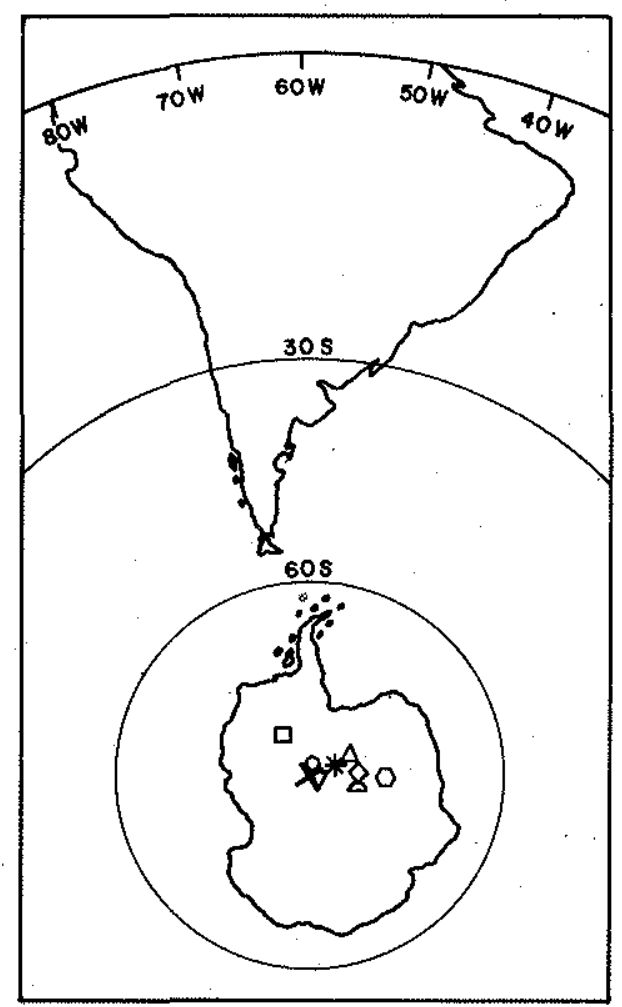

The samples were virtually free of weathering effects and showed little deuteric alteration. They were classified as fresh, fine grained, alkaline volcanic or subvolcanic rocks. Table II shows the potassium-argon ages of these samples. Samples coming from Ponta do Valado and Pico Nossa Senhora de Lourdes contained high percent of atmospheric Ar 40 which explains the high error involved in the age determination. Particularly the age obtained for the sample from Pico Nossa Senhora de Lourdes is high compared with the age of neighboring similar bodies.

Discussion The samples of the Trindade Complex collected from the necks of phonolite of Praia Príncipe, Pico Branco, Pico do Vigia, and Pico Nossa Senhora de Lourdes, the dyke of nephelinite of Praia dos Cabritos and the dyke of tinguaite of Crista do Galo showed normal cleaned magnetic remanences (Table I, Fig. 3). Particularly given the small experimental errors involved in their radiometric ages, the palaeomagnetic polarity and the K-Ar ages for the units of Praia Príncipe, Pico Branco, and Crista do Galo may

Table II - Radiometric ages of alcaline volcanic rocks from Trindade Island

\begin{tabular}{llccccc}
\hline $\begin{array}{c}\text { Sample } \\
\mathrm{N}^{\circ}\end{array}$ & \multicolumn{1}{c}{ Procedence } & $\begin{array}{c}\mathrm{K} \\
\text { Percent }\end{array}$ & $\begin{array}{c}\mathrm{Ar}^{40} \mathrm{rad} . \\
\text { mol. } \\
10^{-10} \mathrm{~g}^{-1}\end{array}$ & $\begin{array}{c}\text { Ar } \\
\text { percent }\end{array}$ & $\begin{array}{c}\text { Age } \\
\text { m.y. }\end{array}$ & $\begin{array}{c}\text { Error } \\
\text { m.y. }\end{array}$ \\
\hline 5225 & Ponta do Valado & 1.57 & 0.033 & 99.2 & 1.2 & 1.0 \\
5213 & Pico do Vigia & 4.88 & 0.246 & 82.4 & 2.8 & 0.5 \\
5216 & Pico N. S. de Lourdes & 5.09 & 0.584 & 91.9 & 6.4 & 3.5 \\
\hline
\end{tabular}


be used to define the Late Cenozoic geomagnetic-time scale. On the basis of a palaeomagnetic and radiometric study carried out with rocks from Oahu and Norfolk Islands, Mc Dougall and Ur-Rahman have recently provided a statistical estimate of $2.41 \pm$ $\pm 0.05 \mathrm{~m}$.y. for the age of the boundary between the Matuyama reversed and the Gauss normal epochs. The normal polarity of the cleaned remanence and the $\mathrm{K}$-Ar ages of the igneous units of Praia Príncipe, Pico Branco, and Crista do Galo do not conflict with this estimate and therefore substantiate it. That age for the Gauss-Matuyama polarity transition agrees rather well with the age suggested for this boundary by sea-floor spreading data (2.41 \pm 0.03 m.y. (Cox, 1969). That would indicate the capacity of sea-floor spreading data to define the age of reversals of the geomagnetic field in recent times.

Valencio et al. (1970) have interpreted the palaeomagnetic and radiometric data for lavas from Neuquén, Argentina, as indicative either "that the Gauss-Matuyama transition would be within the period 2.20-2.31 m.y." or "that a normal event starts between 2.20 and 2.31 m.y." within the Matuyama reversed epoch. Recently, McDougall and Ur-Rahman have found rocks from Hawaii and Norfolk Islands with reverse magnetic remanences whose ages are within 2.21 and $2.39 \mathrm{~m}$.y. Therefore, these data nullify the first interpretation but do not invalidate the second one. The sea-floor spreading data have suggested the presence of a normal polarity event at about $2.24 \mathrm{~m}$.y., and more precisely at $2.30 \pm 0.01$ m.y. (anomaly X, Emilia et al., 1969). It could be considered as an evidence for the presence of a short normal geomagnetic polarity event within the Matuyama reversed epoch. The missing of evidence of this short polarity event in some marine magnetic profiles recorded at the sea surface could be explained taking account that this event lies very close to the boundary between the Matuyama reversed and the Gauss normal epochs (Blakelyand Cox, 1972). We propose the name of Neuquén for the normal polarity event suggested at about 2.30 m.y. within the Matuyama reversed epoch by palaeomagnetic, radiometric, and sea-floor spreading data.

The positions of the virtual geomagnetic poles for the seven geologic units from the Trindade Island included in this paper (Table I) are rather well grouped (Fig. 4). Accepted that they were computed on the basis of the directions of the primary remanence of these geologic units, this suggests that the geomagnetic field in the Trindade Island zone was not strongly affected by secular variation during the time elapsed for the igneous activity in which those geologic units were formed. The vicinity of these seven virtual geomagnetic poles with the geographic pole (Fig. 4) supports this interpretation. Therefore, the strength of the non dipolar geomagnetic field would have been low in this zone of the South Atlantic Ocean during the Late Palaeozoic.

Table I shows the mean of the positions of the seven virtual geomagnetic poles for the Trindade Island given in this paper; this mean pole would represent the Late Cenozoic palaeomagnetic pole for the Trindade Island.

Acknowledgements The authors wish to thank the Universidad de Buenos Aires and the Consejo Nacional de Investigaciones Científicas y Técnicas of Argentina for the financial support which enabled the work described to be carried on. They also wish to thank the Diretoria de Hidrografia e Navegação do Ministério da Marinha from Brazil which made possible the trip between Rio de Janeiro and Trindade Island.

\section{REFERENCES}

ALMEIDA, F. F. M. de - 1961 - Geologia e petrologia da Ilha Trindade. Div. Geol. Min. do Dept. Nac. Prod. Min., Monografia XVIII

BLAKELY, R. J., and COX, A. - 1972 - Evidence for short geomagnetic polarity intervals in the Early Cenozoic. Journal of Geoph. Res., 77 (35): 7 065-7 072 
COX, A. - 1969 - Geomagnetic Reversals. Science, 163: 237-245

CORDANI, U. G. - 1968 - Idade do vulcanismo no Oceano Atlântico Sul. Thesis. University of São Paulo, Brazil.

EMILIA, D. A., and HEINRICHS, D.F. - 1969 - Ocean floor spreading: Olduvai and Gilsa events in the Matuyama Epoch. Science, 166: $1267-1269$

McDOUGALL, I., and AZIZ-UR-RAHMAN - 1972 - Age of the Gauss-Matuyama boundary and of the Kaena and Mammoth Events. Earth and Planet. Sci. Let., 14: 367-380

VALENCIO, D. A., LINARES, E., and CREER, K. M. - 1970 - Palaeomagnetism and K-Ar ages of Cenozoic basalts from Argentina. Geoph. J. R. Astr. Soc., 19: 147-164

VALENCIO, D. A., LINARES, E., and VILAS, J. F. - 1970 - On the age of the Matuyama-Gauss Transition. Earth and Planet. Sci. Letters, 8 (2): 179-182 